\title{
Canine distemper virus detection in asymptomatic and non vaccinated dogs ${ }^{1}$
}

\author{
Helen L. Del Puerto ${ }^{*}$, Anilton C. Vasconcelos ${ }^{2}$, Luciana Moro², Fabiana \\ Alves $^{3}$, Gissandra F. Braz ${ }^{3}$ and Almir S. Martins ${ }^{4}$
}

\begin{abstract}
Del Puerto H.L., Vasconcelos A.C., Moro L., Alves F., Braz G.F. \& Martins A.S. 2010. Canine distemper virus detection in asymptomatic and non vaccinated dogs. Pesquisa Veterinária Brasileira 30(2):139-144. Departamento de Patologia Geral, Instituto de Ciências Biológicas, Universidade Federal de Minas Gerais, Campus Pampulha, Belo Horizonte, MG 31270-901, Brazil. E-mail: helendelpuerto@ hotmail.com

A quantitative real time polymerase chain reaction (PCR) revealed canine distemper virus presence in peripheral blood samples from asymptomatic and non vaccinated dogs. Samples from eleven domestic dogs with no signs of canine distemper and not vaccinated at the month of collection were used. Canine distemper virus vaccine samples in VERO cells were used as positive controls. RNA was isolated with Trizol $\AA$, and treated with a TURBO DNA-free kit. Primers were designed for canine distemper virus nucleocapsid protein coding region fragment amplification (84 bp). Canine $\beta$-actin (93 bp) was utilized as the endogenous control for normalization. Quantitative results of real time PCR generated by ABI Prism 7000 SDS Software showed that $54.5 \%$ of dogs with asymptomatic canine distemper were positive for canine distemper virus. Dissociation curves confirmed the specificity of the real time PCR fragments. This technique could detect even a few copies of viral RNA and identificate subclinically infected dogs providing accurate diagnosis of this disease at an early stage.
\end{abstract}

INDEX TERMS: Asymptomatic, canine distemper, diagnosis, dogs.

RESUMO.- [Detecção do vírus da cinomose canina em cães assintomáticos e não vacinados.] $A$ reação em cadeia da polimerase (PCR) em tempo real revelou a presença do vírus da cinomose canina em amostra de sangue de cães assintomáticos e não vacinados. Amostra de onze cães domésticos sem nenhum sinal clínico de cinomose e que não foram vacinados no mês da coleta de sangue foram utilizados para análise. Amostra vacinal do vírus da cinomose canina em células VERO foi utilizada como controle positivo. O RNA total foi isolado utilizandose Trizol囚, e tratadas com o Kit TURBO DNA-free. Os

\footnotetext{
${ }^{1}$ Received on July 13, 2009.

Accepted for publication on November 19, 2009.

2 Departamento de Patologia Geral, Instituto de Ciências Biológicas (ICB), Universidade Federal de Minas Gerais (UFMG), Av. Antônio Carlos 6627, Campus Pampulha, Belo Horizonte, MG 31270-901, Brazil. *Corresponding author: helendelpuerto@ hotmail.com

${ }^{3}$ Departamento de Medicina Veterinária Preventiva da Escola de Veterinária, UFMG, Campus Pampulha, Belo Horizonte, MG, Brazil.

${ }^{4}$ Departamento de Fisiologia e Biofísica, ICB, UFMG, Campus Pampulha, Belo Horizonte, MG.
}

iniciadores foram desenhados para amplificar a região do nucleocapsídeo viral com 319pb e 84pb para a PCR convencional e PCR em tempo real, respectivamente. O fragmento alvo da $\beta$-actina canina com $93 \mathrm{pb}$ foi utilizado como controle endógeno e normalizador. Resultados quantitativos da PCR em tempo real gerados pelo programa $A B I$ Prism 7000 SDS demonstraram que $54,5 \%$ dos cães assintomáticos foram positivos para o vírus da cinomose canina. As curvas de dissociação confirmaram a especificidade dos fragmentos da PCR em tempo real. A detecção precoce do RNA viral é importante para a identificação de cães subclinicamente infectados e limitar a difusão da doença.

TERMOS DE INDEXAÇÃO: Assimtomáticos, cinomose canina, diagnóstico, cães.

\section{INTRODUCTION}

Canine Distemper (CD) is a pantropic worldwide infectious disease caused by canine distemper virus (CDV), a member of the genus Morbillivirus within the family Paramyxoviridae. CDV has an enveloped virion containing 
a nonsegmented negative-stranded RNA genome, which comprises approximately 16 Kilobases (Kb). Six genes encode for a single envelope-associated protein (M), two glycoproteins (the hemagglutinin $\mathrm{H}$ and the fusion protein $\mathrm{F})$, two transcriptase-associated proteins (the phosphoprotein $\mathrm{P}$ and the large protein $\mathrm{L}$ ), and the nucleocapsid protein $(\mathrm{N})$ that encapsulates the viral RNA (Moss \& Griffin 2006). The $\mathrm{H}$ gene protein is used for attachment to receptors on the cell in the first step of infection, and an adequate host immune response against the $\mathrm{H}$ protein may prevent CDV infection (von Messling et al. 2001). After attachment, the $\mathrm{F}$ protein promotes fusion of the viral envelope with the host cell membranes, and also promotes membrane fusion between the host cells, with formation of syncytia (Lamb et al. 2006). The M protein links ribonucleoproteins with envelope proteins during virion assembly, and the $\mathrm{P}$ protein regulates transcription, replication, and the efficiency with which the nucleoprotein assembles into nucleocapsids (Moss \& Griffin 2006). The nucleocapsid gene is considered a conserved region among different CDV strains, while $\mathrm{H}$ gene is subjected to higher genetic and antigenic variation than other CDV genes, the amino acid sequence vary by approximately $10 \%$ among different CDV strains (Martella et al. 2008). The linear arrangement and position genome of the six genes on CDV are respectively: $\mathrm{N}, \mathrm{P}, \mathrm{M}, \mathrm{F}, \mathrm{H}$, and $\mathrm{L}$.

Canine distemper (CD) is one of the most important viral diseases in dogs in the world (Krakowka et al. 1980a), causing morbidity and mortality in non-vaccinated dogs and also in animals that were previously vaccinated (Krakowka et al. 1980b, Tipold et al. 1992, Summers et al. 1995). In Brazil at least two studies (Bentubo et al. 2007, Fighera et al. 2008) have shown that canine distemper is the most important cause of death or euthanasia in dogs. In one of these studies (Fighera et al. 2008), 12.4\% of the dogs died or were submmited to euthanasia due to infection by canine distemper virus.

Variable clinical signs may be present, making the clinical diagnostic difficult (Appel \& Summers 1995). Contact among infected (clinic or subclinical) dogs maintains the virus within the dog population (Greene \& Apple 2006), mainly puppies (3-6 mo) who are susceptible to infection, due to the loss of maternal antibodies (Krakowka \& Koestner 1976). However, canine distemper is also a common disease in adult Brazilian dogs (between 1 and 9 years old) and corresponds to the main cause of death in dogs within this average age (12.4\%) (Fighera et al. 2008).

Vaccination against $C D$ has been used widely for decades, but CDV infection is still an important disease (Elia et al. 2006). Any febrile condition of puppies with multisystemic symptoms should consider CDV infection.

Several laboratory tests are available to confirm clinical CDV infection; however most of the commonly used tests may not be sensitive, specific, and quantitative enough to detect subclinical infection. Immunofluorescence (IF) on conjunctival, nasal, and vaginal smears can detect CDV antigens only within 3 weeks after infection, when the virus is still present in the epithelial cells (Appel 1987), but it has low sensitivity and can generate false negative diagnoses. Virus isolation on cell lines from clinical samples is fastidious. ELISA assay may detect high antibody titers to CDV for several months after vaccination or after subclinical or clinical infection, turning false positive results (Martella et al. 2008). Molecular assays, such as RT-PCR (Frisk et al. 1999, Kim et al. 2001, Rzezutka \& Mizak 2002, Gebara et al. 2004) are sensitive and specific, but not quantitative.

Canine subclinical infection by CDV contributes to the spread of the disease, requesting the development of a more sensitive diagnostic technique for early detection and quantification in asymptomatic animals and in those with subclinical infection. The quantitative real time PCR technique has been used for CDV detection and quantification in blood samples, conjunctive swabs, urine, and tissues in dogs showing clinical signs of disease, and also in infected VERO cells (Elia et al. 2006, Scagliarini et al. 2007). The objective of this study was to use quantitative real time PCR for CDV screening in peripheral blood samples of dogs with asymptomatic CD.

\section{MATERIALS AND METHODS}

\section{Animals}

Blood samples from fourteen dogs of different breeds, ages, and sexes were collected with the owners' permission, in Belo Horizonte, Minas Gerais, Brazil. Subclinical infection group had eleven animals with no clinical signs of any disease, and no vaccination during the last thirty days. To contrast that, blood samples from three other dogs with clinical signs of $C D$ (including listlessness, decreased appetite, fever, and oculonasal discharge) were collected.

\section{Positive control}

Vaccine samples (Onderstepoort and Rockborn) cultivated in VERO cells were used as positive controls. They also allowed the construction of a dilution curve for the absolute quantification of the samples tested in real time PCR. Vaccine samples were kindly supplied ${ }^{5}$.

\section{RNA isolation and reverse transcription (RT)}

RNA was isolated from $300 \mu$ l of either total peripheral blood homogenate or VERO cell CDV positive controls using Trizol ${ }^{\circledR 6}$. Samples were treated with TURBO DNA-free kit? ${ }^{7}$. Reverse transcription (RT) was performed. Briefly, $2 \mu \mathrm{g}$ of RNA were reversely transcribed in a $40 \mu \mathrm{l}$ reaction mixture containing 40 $\mathrm{U}$ of Moloney Murine Leukemia Virus Reverse Transcriptase ${ }^{8}$, 25 pmols of each reverse oligonucleotide primer (Table 1), $4 \mu \mathrm{l}$

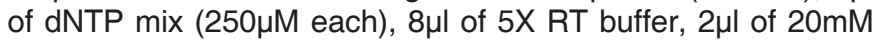
DTT, and RNAse-free water to complete the final volume. The

\footnotetext{
${ }^{5}$ Dr. Marilene Camargos, Laboratório Labovet Produtos Veterinários Ltda, Feira de Santana, Bahia, BA.

6 Trizol $^{\circledR}$, Invitrogen Corporation, Rua Breno Ferraz do Amaral 390/ 408, Jd. da Saúde, São Paulo, SP.

${ }^{7}$ Applied Biosystems, 850 Lincoln Centre Drive, Foster City, CA, USA.

8 Invitrogen Corporation, 5791 Van Allen Way, Carlsbad, CA, USA.
} 
Table 1. PCR primers VCC01/VCC02 used in gel-based PCR and VCCIN/VCC01 used in real time used for CDV

\begin{tabular}{|c|c|c|c|}
\hline Primers & Nucleotide sequence (nt) & $\begin{array}{l}\text { Fragment } \\
\text { size }\end{array}$ & $\begin{array}{l}\text { mRNA } \\
\text { position }\end{array}$ \\
\hline $\begin{array}{l}\text { FORBETADOG } \\
\text { (forward) }\end{array}$ & 5'-CACCTTCTACAACGAGCTGCG -3' & $93 \mathrm{bp}$ & $(264-284)$ \\
\hline $\begin{array}{c}\text { REVBETADOG } \\
\text { (reverse) }\end{array}$ & 5'-ATCTTCTCACGGTTGGCCTTG-3' & & $(502-482)$ \\
\hline $\begin{array}{l}\text { VCCIN } \\
\text { (reverse) }\end{array}$ & 5'-TAGCATAACTCCAGAGCAATG -3' & $84 \mathrm{bp}$ & $(1116-1096)^{*}$ \\
\hline $\begin{array}{l}\text { VCC01 } \\
\text { (forward) }\end{array}$ & 5'-CAGCACCGTACATGGTTATC -3' & & $(1033-1052)^{*}$ \\
\hline $\begin{array}{l}\text { VCC02 } \\
\text { (reverse) }\end{array}$ & 5'-GATTGCTTAGGACCAGTAGC -3' & $319 \mathrm{bp}$ & $(1351-1332)^{*}$ \\
\hline $\begin{array}{l}\text { AGT 1(RC) } \\
\text { (forward) }\end{array}$ & 5'TCCACAGATCCGTGATGACTC-3' & $298 \mathrm{bp}$ & \\
\hline $\begin{array}{l}\text { AGT 2(RC) } \\
\text { (reverse) }\end{array}$ & 5'-GCAGCTCGCTGCCGATCCTC-3' & & \\
\hline
\end{tabular}

reaction mixture was incubated at $42^{\circ} \mathrm{C}$ for $1 \mathrm{~h}$, placed on ice and cooled to $4^{\circ} \mathrm{C}$, and either used immediately for PCR or kept at $-80^{\circ} \mathrm{C}$ for later use.

\section{Gel-based RT-PCR}

Canine distemper virus nucleocapsid cDNA and canine housekeeping gene $\beta$-actin were amplified by conventional PCR, using positive control cDNA samples (infected VERO cells) and dog cDNA samples. Specific primers were designed for gel-based RT-PCR using the sequences obtained in GeneBank, through the Blast program (http://www.ncbi.nlm.nih.gov/blast/blast.cgi). Subsequently, all the sequences were analyzed using the Integrated DNA technologies website (http://www.idtdna.com), and specific primers that amplified a $319 \mathrm{bp}$ amplicon for CDV and $93 \mathrm{bp}$ for $\beta$-actin were designed (Table 1). Exon 2 of rat angiotensinogen (AGT), which amplified a 298 bp amplicon was used as PCR reaction control (RC). Conventional PCR reaction occurred under the following cycling conditions: denaturation at $95^{\circ} \mathrm{C}$, annealing at $56^{\circ} \mathrm{C}$ and extension at $72^{\circ} \mathrm{C}$ for 40 cycles. Target amplicons of positive controls were agarose gel purified using Zymoclean ${ }^{\mathrm{TM}}$ Gel DNA Recovery $\mathrm{Kit}^{9}$, and quantified to create serial dilutions ranging from $1 \mathrm{ng}$ to $10^{-9} \mathrm{ng}$ to obtain a standard curve for the real time PCR absolute quantification. Primers pairs for CDV nucleocapsid gene were selected based on their conservation among different CDV strains.

\section{Quantitative real time PCR}

Absolute quantitative real time PCR was performed to detect fragments of $84 \mathrm{bp}$ for CDV, within nucleocapsid gene; and 93 bp for canine $\beta$-actin. Specific primers were designed as described in gel-based RT-PCR (Table 1). Real time PCR was performed with an $\mathrm{ABI}$ Prism ${ }^{\circledR} 7000$ Sequence Detection System ${ }^{10}$, using SYBR $^{\circledR}$ Green Master Mix ${ }^{11}$. PCR reactions were set up in an isolated room, and gloves, face masks, and barrier tips were used during all experiments. The final PCR mixture contained $1.5 \mu \mathrm{l}$ each of forward and reverse primers (final concentration 1.5pmols each), $2 \mu \mathrm{l}$ of cDNA from RT, $10 \mu \mathrm{l}$ of $\mathrm{Sybr}^{\circledR}$ Green Mix ${ }^{11}$ and $5 \mu$ l of PCR water, in a final volume of $20 \mu l$. Universal cycling conditions were as specified by $\mathrm{ABI}(2$ min at $50^{\circ} \mathrm{C}, 10 \mathrm{~min}$ at $95^{\circ} \mathrm{C}, 40$ cycles of $15 \mathrm{~s}$ at $95^{\circ} \mathrm{C}$, and $1 \mathrm{~min}$ at $60^{\circ} \mathrm{C}$ ). Cycle threshold values were determined by automated threshold analysis of ABI Prism software (v.1.0).
The amplification efficiency $\left(E=10^{\{-1 / \text { slope }\}}\right)$ was determined by the slope of the specific standard curve. The linearity was determined by regression coefficient $\left(r^{2}\right.$ value $\geq 0.987$ ) (Pfaffl 2001). The absolute quantitative expression level values were given in nanograms (ng) for each sample, calculated from standard curve dilution by the ABI Prism 7000 SDS Software. Dissociation curves were always analyzed to confirm gene target specificity.

\section{RESULTS}

\section{Gel-based RT-PCR}

The conventional PCR results confirmed CDV detection in positive controls (CDV vaccine samples - Onderstepoort and Rockborn - in VERO cells), in the three sick dogs $(100 \%)$, and in three out of eleven asymptomatic dogs (27\%), amplifying a fragment of $319 \mathrm{bp}$, and also the internal control $\beta$-actin of 93 bp (Fig.1). Agarose gel purification results in $8 \%$ polyacrylamide gel demonstrated the specificity of the CDV and $\beta$-actin fragments (Fig.2).

\section{Quantitative real time PCR}

The quantitative real time PCR was obtained by construction of standard curves for CDV and $\beta$-actin using purified standard amplicons of known quantities, which were used in serial dilutions of $1 \mathrm{ng}$ to $10^{-9} \mathrm{ng}$. Standard curves demonstrated high linearity $(r 2>0.99)$ for both targets studied, and the slopes were less than -2.0; that is, the efficiency $\left(E=10^{\{-1 / \text { slope }\}}\right)$ of all reactions was $100 \%$. The quantification of CDV in each sample was given as $\mathrm{ng}$ of $\mathrm{CDV} / \mathrm{ng}$ of $\beta$-actin. Dissociation curves were unique for each amplicon and confirmed gene target specificities (Fig.3). The quantitative real time PCR was able to detect

\footnotetext{
${ }^{9}$ Zymoclean $^{\mathrm{TM}}$, Zymo Research, 625 West Katella Avenue Suite 30, Orange, CA, USA.

${ }^{10}$ ABI Prism ${ }^{\circledR} 7000$ Sequence Detection System, Applied Biosystems do Brasil, Avenida do Café 277, Vila Guarani, São Paulo, SP.

${ }^{11}$ SYBR $^{\circledR}$ Green Master Mix, Invitrogen Corporation, 5791 Van Allen Way, Carlsbad, CA, USA.
} 
Fig.1. Typical CDV gel-based PCR diagnostic test of total blood using VCC01/VCC02 primers. Samples are from positive controls CDV vaccine samples - Onderstepoort and Rockborn - in VERO cells (PC1 and 350 bp PC2, respectively); 3 clinically suspected $300 \mathrm{bp}$ dogs (SD1-SD3); and 11 asymptomatic 250 bp dogs (AD1-AD11). 3-5ul of the amplification reaction were applied and visualized by silver stained $8 \%$ polyacrylamide gel, after electrophoresis at $100 \mathrm{~V} / 50 \mathrm{~min}$. CDV specific amplicon of $319 \mathrm{bp}$ is indicated, $300 \mathrm{bp}$ and the $\beta$-actin 93 bp normalizer is shown $250 \mathrm{bp}$ for each sample. Ladder: 50 bp DNA ladder $(0.3 \mu \mathrm{g})$; RC: PCR reaction control (AGT) amplicon of 298 bp; Blank: no template negative control.

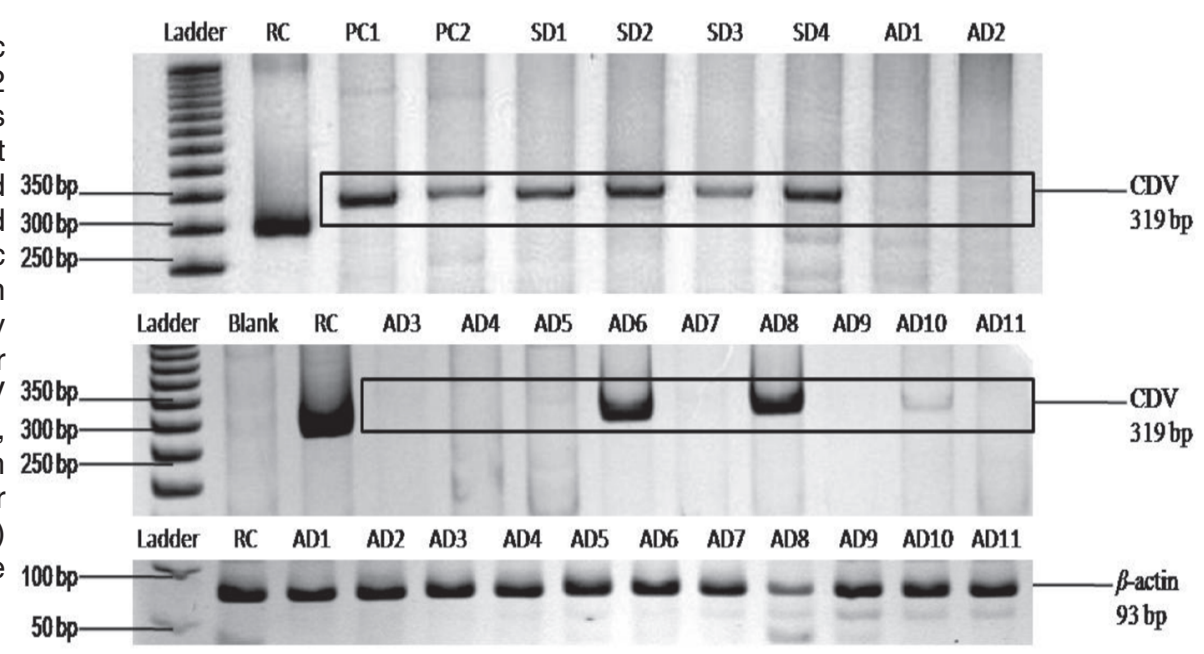

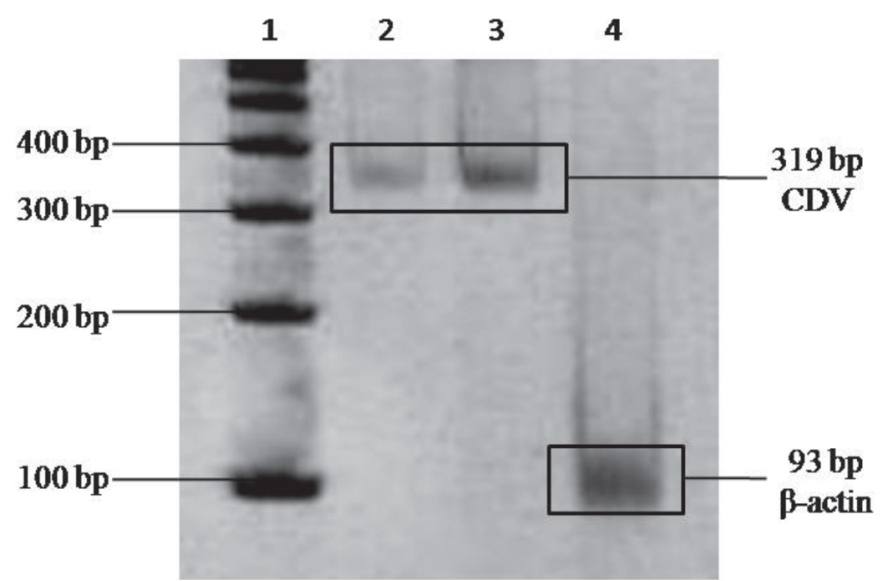

Fig.2. 8\% polyacrylamide gel showing the purity and integrity of CDV and $\beta$-actin fragments, with $319 \mathrm{bp}$ and $93 \mathrm{bp}$, respectively. 1 : $2 \mu \mathrm{l}$ of $100 \mathrm{bp}$ DNA ladder; 2 : $15 \mu \mathrm{l}$ of CDV amplicon (Onderstepoort); 3: 15 $\mu$ l CDV amplicon (Rockborn) and $4: 15 \mu$ l of $\beta$-actin fragment.
CDV in 6 out of 11 animals (54.5\%) (Fig.4). Amplification of the internal control $\beta$-actin was observed in all samples and was used to normalize the CDV quantification in each sample.

\section{DISCUSSION}

Canine distemper (CD), one of the most fatal diseases in puppies, remains an important viral disease in the veterinary field. Unfortunately, there is still no effective therapy for CD, only symptomatic treatments (Kajita et al. 2006). CDV enters by the nasal or oral route and starts replication in the lymphoid tissues (Appel 1969), resulting in immunosuppression. The incubation period may range from 1 to 4 weeks or more. Transient fever reaches a peak 3 to 6 days after infection and is associated with the initial virus spread in the body. By days 6 to 9 after infection, CDV spreads by cell-associated viremia to the epithelial cells in most organs (Appel et al. 1982). If the dog develops
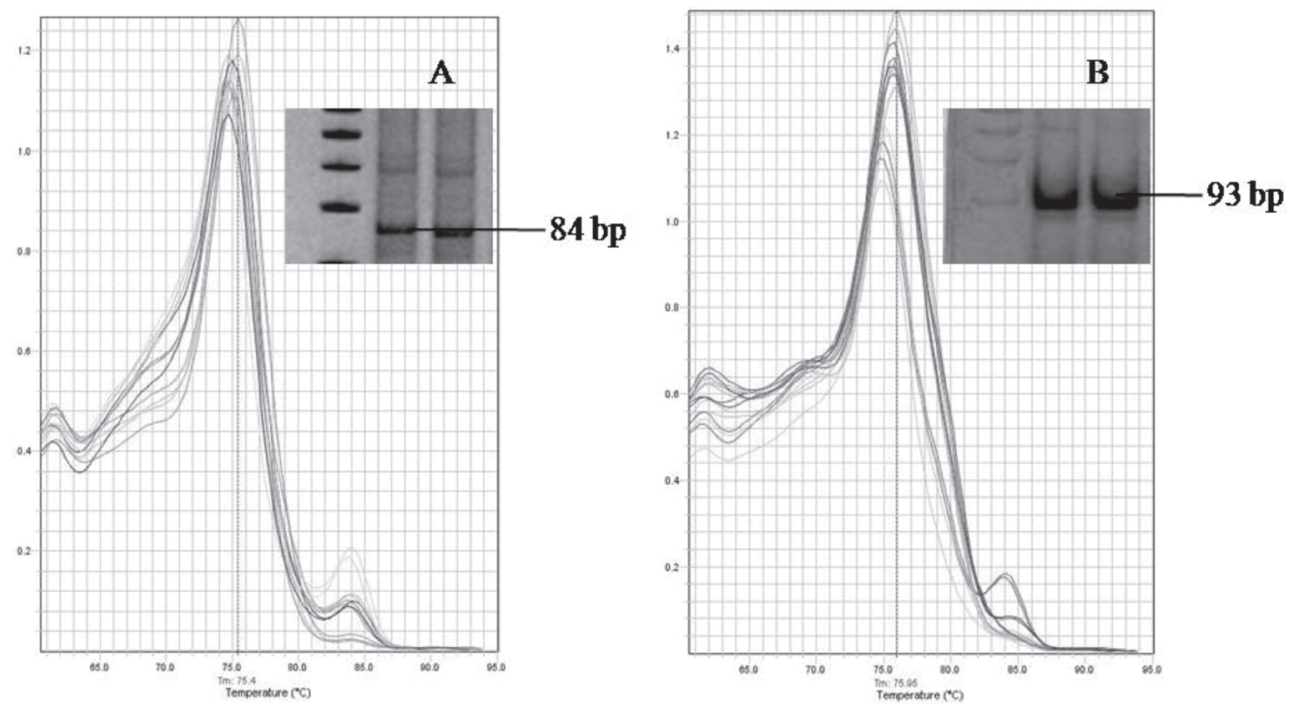

Fig.3. (A) and (B) shows the dissociation curve for CDV and $\beta$-actin, respectively, to check the specificity and size of the amplified fragments by real time PCR. $8 \%$ polyacrylamide gel confirms the CDV $84 \mathrm{bp}$ fragment and $\beta$-actin $93 \mathrm{bp}$, after the real time PCR reaction. 


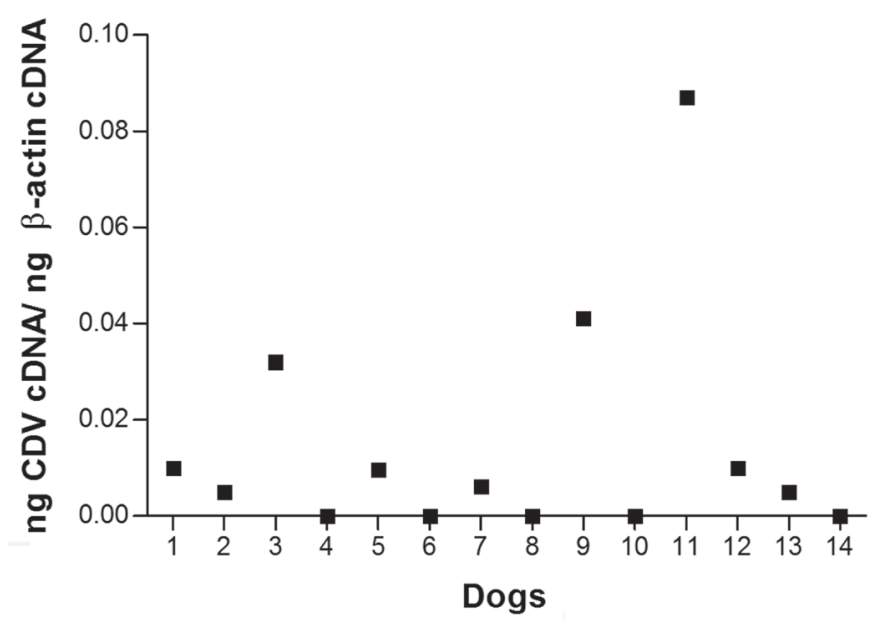

Fig.4. The CDV detection occurred in all 3 symptomatic dogs' samples tested (100\%). Symptomatic dogs 1 (SD1), 2 (SD2) and 3 (SD3), with a viral amount of $0.041,0.087$ and $0.032 \mathrm{ng}$, respectively. The CDV detection occurred in 6 out of 11 asymptomatic dogs' samples tested (54.5\%). Asymptomatic dogs: 5 (AD2), 7 (AD4), 9 (AD6), 11 (AD8), 12 (AD9) and 13 (AD10), with a viral amount of 0.096, 0.0621, 0.041, 0.087, 0.01 and $0.003 n g$, respectively. Asymptomatic dogs: 4 (AD1), 6 (AD3), 8 (AD5), 10 (AD7) and 14 (AD11) with no CDV detection.

a strong immune response, the virus gets cleared from the tissues and the animal recovers from the infection. Dogs that fail to mount an immune response will show continuous virus replication and spreading massively throughout the body (Martella et al. 2008). Thus, infection relies on diseased and also on subclinically infected dogs.

A quantitative real time PCR assay using blood samples to detect asymptomatic infection in dogs would help to detect the virus during viremia, before it reaches epithelial cells and be detectable in animal secretions and excretions. So far, there is no data reporting the percentage of CDV infected dogs with subclinical CD on a population. Thus, it is urgent and necessary a sensitive, specific and quantitative assay to perform such epidemiological study.

The application of molecular techniques (for example, gel-based RT-PCR) in CDV diagnosis has been successfully used in different types of samples collected from animals clinically suspected of infection (Frisk et al. 1999, Kim et al. 2001, Rzezutka \& Mizak 2002, Gebara et al. 2004). It is a specific, practical and rapid tool in CDV diagnosis ante mortem considering the non-specific clinical signs of the disease, but it is not a quantitative and very sensitive assay.

Immunohistochemistry technique in naturally CDVinfected dogs has been used as an auxiliary tool in post mortem CDV detection (Sonne et al. 2009). The conventional RT-PCR combined with nested PCR demonstrated increased sensitivity of CDV detection (Kim et al. 2001), enabling the detection of CDV nucleoprotein (NP) in animals recently vaccinated with the attenuated virus and resulting in CDV detection in 4 out of 5 animals within 2 to 7 days of vaccination. However, no CDV detection was observed after 14 days of vaccination (Kim et al. 2001). It is estimated that $25 \%$ to $75 \%$ of dogs susceptible to CD are subclinically infected and are transmitting the virus without any clinical sign of disease (Greene \& Apple 2006).

In addition, asymptomatic dogs are not diagnosed and remain as a CDV reservoir. Hence, the use of gel-based $P C R$ is useful but not enough to detect CDV in asymptomatic animals, because it is a qualitative and not a quantitative technique. Nowadays, studies with other viral diseases, such as HIV, have been done using the real time PCR technique to evaluate the efficiency of antiviral drugs, allowing for virus quantification during treatment (Malnati et al. 2008). Quantitative real time PCR based on the CDV nucleocapsid gene showed itself to be highly sensitive, capable of detecting $10^{-4} \mathrm{ng}$ of virus cDNA and proving to be more sensitive than gel-based conventional PCR.

In addition, gel-based RT-PCR was able to detect CDV infection in 3 out of $11(27 \%)$ asymptomatic dogs, while real time PCR assay was able to detect CDV infection in 6 out of $11(54.5 \%)$ asymptomatic dogs, being more sensitive and quantitative than conventional RT-PCR assay. This confirms real time PCR as an important tool for virus quantification suitable for research and diagnostic purposes. Unfortunately, no information on later clinical history in those 6 animals, CDV positive in real time diagnosis, could be obtained. Further work is needed to evaluated canine distemper virus prevalence in asymptomatic dog's populations. This would include a larger sample and different seasonal sampling. A quantitative real time PCR reaction in asymptomatic dog's secretions would be helpful to answer this question. The detection of even a few copies of viral RNA is particularly useful for the identification of subclinically infected dogs that contribute to the diffusion of the disease; accurate diagnosis of this disease at an early stage is required to quarantine any infected animals and to prevent the spread of the disease.

Acknowledgements.- To Conselho Nacional de Desenvolvimento Científico e Tecnológico (CNPq) and to Fundação de Amparo à Pesquisa do Estado de Minas Gerais (FAPEMIG) for financial support, and to Dr. Marilene Camargos for the CDV vaccinal strains. Portion of these data were published in abstract form in The Ohio Journal of Science 108 (1): A-27, poster board number 041, Ohio, USA in April, 2008.

\section{REFERENCES}

Appel M.J. 1969. Pathogenesis of canine distemper. Am. J. Vet. Res. 30:1167-1182.

Appel M.J. 1987. Virus infection of carnivores. Elsevier, Amsterdam, p.133-159.

Appel M.J., Shek W.R. \& Summers B.A. 1982. Lymphocyte-mediated immune cytotoxicity in dogs infected with virulent canine distemper virus. Infect. Immun. 37:592-600.

Appel M.J. \& Summers B.A. 1995. Pathogenicity of morbilliviruses for terrestrial carnivores. Vet Microbiol. 44:187-191.

Bentubo H.D.L., Tomaz M.A., Bondan E.F. \& Lallo M.A. 2007. Expectativa de vida e causas de morte em cães na área metropolitana de São Paulo (Brasil). Ciência Rural 37:1021-1026. 
Elia G., Decaro N., Martella V., Cirone F., Lucente M.S., Lorusso E., Di Trani L. \& Buonavoglia C. 2006. Detection of canine distemper virus in dogs by real-time RT-PCR. J. Virol. Methods 136: 171-176.

Fighera R.A., Souza T.M., Silva M.C., Brum J.S., Graça D.L., Kommers G.D., Irigoyen L.F. \& Barros C.S.L. 2008. Causas de morte e razões para eutanásia de cães da Mesorregião do Centro Ocidental RioGrandense (1964-2004). Pesq. Vet. Bras. 28:223-230.

Frisk A.L., Konig M., Moritz A. \& Baumgartner W. 1999. Detection of canine distemper virus nucleoprotein RNA by reverse transcriptionPCR using serum, whole blood, and cerebrospinal fluid from dogs with distemper. J. Clin. Microbiol. 37:3634-3643.

Gebara C.M.S., Wosiacki S.R., Negrão F.J., Oliveira D.B., Beloni S.N.E. \& Alfieri A.A. 2004. Detecção do gene da nucleoproteína do vírus da cinomose canina por RT-PCR em urina de cães com sinais clínicos de cinomose. Arq. Bras. Vet. Zootec. 56:480-487.

Greene C.E. \& Apple M.J. 2006. Canine distemper, p.25-41. In: Greene C.E. (Ed.), Infectious Diseases of the dog and cat. $3^{\text {rd }}$ ed. Saunders Elsevier, St Louis.

Kajita M., Katayama H., Murata T., Kai C., Hori M. \& Ozaki H. 2006. Canine distemper virus induces apoptosis through caspase- 3 and -8 activation in vero cells. J. Vet. Med. B, Infect. Dis. Vet. Public Health 53:273-277.

Kim Y.H., Cho K.W., Youn H.Y., Yoo H.S. \& Han H.R. 2001. Detection of canine distemper virus (CDV) through one step RT-PCR combined with nested PCR. J. Vet. Sci. 2:59-63.

Krakowka S., Higgins R.J. \& Koestner A. 1980a. Canine distemper virus: Review of structural and functional modulations in lymphoid tissues. Am. J. Vet. Res. 41:284-292.

Krakowka S., Higgins R.J. \& Metzler A.E.1980b. Plasma phase viremia in canine distemper virus infection. Am. J. Vet. Res. 41:144-146.

Krakowka S. \& Koestner A. 1976. Age-related susceptibility to infection with canine distemper virus in gnotobiotic dogs. J. Infect. Dis. 134:629632.
Lamb R.A., Paterson R.G. \& Jardetzky T.S. 2006. Paramyxovirus membrane fusion: Lessons from the $\mathrm{F}$ and $\mathrm{HN}$ atomic structures. Virology 344:30-37.

Malnati M.S., Scarlatti G., Gatto F., Salvatori F., Cassina G., Rutigliano T., Volpi R. \& Lusso P. 2008. A universal real-time PCR assay for the quantification of group-M HIV-1 proviral load. Nat. Protoc. 3:1240-1248.

Martella V., Elia G. \& Buonavoglia C. 2008. Canine distemper virus. Vet. Clin. North Am., Small Anim. Pract. 38:787-797.

Moss W.J. \& Griffin D.E. 2006. Global measles elimination. Nat. Rev. Microbiol. 4:900-908.

Pfaffl M.W. 2001. A new mathematical model for relative quantification in real-time RT-PCR. Nucleic Acids Res. 29:45.

Rzezutka A. \& Mizak B. 2002. Application of N-PCR for diagnosis of distemper in dogs and fur animals. Vet. Microbiol. 88:95-103.

Scagliarini A., Dal Pozzo F., Gallina L., Vaccarini F. \& Morganti L. 2007. TaqMan based real time PCR for the quantification of canine distemper virus. Vet. Res. Commun. 31:261-263.

Sidhu M.S., Husar W., Cook S.D., Dowling P.C. \& Udem S.A. 1993. Canine distemper terminal and intergenic non-protein coding nucleotide sequences: Completion of the entire CDV genome sequence. Virology 193:66-72.

Sonne L., Oliveira E.C., Pescador C.A., Santos A.S., Pavarini S.P., Carissimi A.S. \& Driemeier D. 2009. Pathologic and immunohistochemistry findings in dogs naturally infected by canine distemper virus. Pesq. Vet. Bras. 29:143-149.

Summers B.A., Cummings J.F. \& De Lahunta A. 1995. Veterinary Neuropathology. Mosby, St Louis, p.95-188.

Tipold A., Vandevelde M. \& Jaggy A. 1992. Neurological manifestations of canine distemper virus infection. J. Small Anim. Pract. 33:466-470.

von Messling V., Zimmer G., Herrler G., Haas L. \& Cattaneo R. 2001. The hemagglutinin of canine distemper virus determines tropism and cytopathogenicity. J. Virol. 75:6418-6427. 